\title{
Pandemic, crisis and perspectives: spatial and territorial insights on the CoViD-19
}

Call for paper for thematic issue

Sophie Baudet-Michel, Emmanuel Eliot, Yohan Fayet and Sébastien Fleuret

\section{OpenEdition}

Journals

Electronic version

URL: http://journals.openedition.org/rfst/783

ISSN: 2492-3672

Publisher

Espaces et SOciétés (UMR 6590)

Electronic reference

Sophie Baudet-Michel, Emmanuel Eliot, Yohan Fayet and Sébastien Fleuret, "Pandemic, crisis and perspectives: spatial and territorial insights on the CoViD-19", Revue francophone sur la santé et les territoires [Online], Pandemic, crises and perspectives: territorial readings of Covid-19, Online since 05 May 2020, connection on 06 April 2021. URL: http://journals.openedition.org/rfst/783

This text was automatically generated on 6 April 2021.

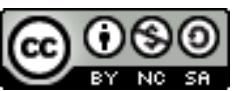

La Revue francophone sur la santé et les territoires est mise à disposition selon les termes de la Licence Creative Commons Attribution - Pas d'Utilisation Commerciale - Partage dans les Mêmes Conditions 4.0 International. 


\section{Pandemic, crisis and perspectives: spatial and territorial insights on the CoViD-19}

Call for paper for thematic issue

Sophie Baudet-Michel, Emmanuel Eliot, Yohan Fayet and Sébastien Fleuret

1 The emerging pathogen responsible for the CoViD-19 outbreak was first notified in the Wuhan area (China) in December 2019. It turned into a pandemic in less than three months. It led to the lockdown of half of the world's population in order to limit its spread and reduce the pressure on health care systems This pandemic has many geographical dimensions 1) in terms of diffusion 2) in the crisis management (economic, social, etc.) 3) in the set up of policies (before, during and after the lockdown). Biomedical research has quickly got into gear to adress the health challenges imposed by this pandemic. Undoubtedly, there is a need for insights from different disciplines with a spatial territorial perspective on this pandemic.

2 The call for paper below is a non-exhaustive proposal for which the RFST is expecting contributions.

For a contribution, please: contact.rfst@gmail.com

\section{CoViD-19: Spatial and Social issues in the pandemic management}

3 The extent and brutality of the pandemic led to the implementation of exceptional measures to limit its spread.

4 The lockdown and the set of social distancing measures constitute an unprecedented experience whose effects on the general population have not yet been fully assessed. How has the lockdown been put into practice in France and elsewhere? What are the social and spatial disparities in living in lockdown (in particular difficulty or not to 
respect quarantine)? What are the consequences of the lockdown for vulnerable populations (homeless, migrants, elderly, deprived populations) and on health inequalities?

5 The brutality of the pandemic also questions the transformation of the healthcare systems. The crisis highligths difficulties and shortcuts as well as new forms of cooperation and innovation. These transformations can also be observed in the populations access to health care (changes, refusals, renunciations, adaptations...) at different scales (local organisation of care, globalised supply chain).

Beyond the polemics, the brutality of the CoViD-19 pandemic invites to (re)examine the recent evolution of the health care systems and their capacities to respond to the emergency? How did health care systems cope with this new situation? For example what are the roles of regional and local authorities in the management of the crisis? What is the management of the pandemic in other countries, particularly those with highly decentralized health care systems or in developing countries? What are the roles of private actors, Non-Governmental Organizations or community health care systems in the support and the solutions provided to populations? Finally, considering the mortality caused by this pandemic, texts related to death and end-of-life rites can provide an original contribution.

\section{CoViD-19: Data and methodological issues}

7 Evaluating CoViD-19 infection is a major issue since available data may present: a) Different ways of measurement (data based on mortality, data based on tests, data on symptomatics, asymptomatics cases...); b) Data sets differences from a country to another (variations in spatial / administrative references); c) Changes over times due to differences in testing facilities, in recording mortality data...

What are the methodological options for comparing CoViD-19 infection between countries, between regions, places...? Which level for which analysis?

What are the options to compensate the lack or the weakness of these data? What are the added values of complementary sources like scientific blogs, collective databases, shared platforms, online enquiries, qualitative data...for analysing the epidemic? What are the impacts of the development of such types of data in terms of: empowerment of people in places, development of different knowledge on the pandemic from a place to another, responses to risk management in space and places...

10 What are the problems raised by the development of technologies using tracking? How may they help in understanding the spatial dynamic of the epidemic? Could the resistance or acceptance of those technologies among citizen influence the epidemic courses? How can they help in managing crisis in places? The increase of tracking data, even temporary, question social and spatial control. What control and involvement should citizen have on both the data collection and its use in places?

11 What does expertise on the pandemic tell us about the relationship between sciences and politics? For which purposes or objectives? For instance, analysis based on the use of cartography or spatial modeling are at stake. 


\section{CoViD-19: Geopolitical aspects of the pandemic: Borders, mobilities, globalization}

12 As an emerging disease, the CoViD 19 highlights the gaps, tensions, and risks of the contemporary world.

What can we observe in terms of differences / closeness, new forms / lack of cooperation, power struggles? What kind of relations does the pandemic reveal between different actors: between states, between Nations and the World Health Organization, between international donors, between foundations or international NGOs?

14 How does the spread of CoViD-19 recreate borders and question the cross-border relationships at local or global scales? In many countries, decisions were taken to close borders, to control movements or to restrain them: is it a sign of the resurgence of spatial constraints?

15 How will the challenges of the pandemic be linked (or not) to the medium and long term environmental issues: climate change, limitation of greenhouse gas emissions, biodiversity, etc.?

16 From the perspective of the medical supply chain, how does the pandemic call into question the regional economic specializations and the abandonment of the production of strategic healthcare materials (tests, masks, chemicals solutions...)? Which geopolitical and intermediary linchpins actors did the crisis reveal?

17 Finally, the pandemic brings back fears and perceptions that are often common to epidemics: conspiracy, scapegoats, places perceived "at risk". How does CoViD-19 reinterpret antagonisms within societies: how are people and places depicted, perceived or stigmatized during the pandemic?

18 To sum up, the variety of representations of the disease, the challenges associated with the circulation of information, the diversity of responses across the world, the struggles for influence in international politics, are opening up new global geopolitics, including geohealth.

The texts expected in this call for paper may be of various shape: long articles (case studies, literature reviews, summary notes or data analysis, etc.), short articles (research positions, critical analysis) or working - or data papers.

Considering the very special nature of the CoViD-19 crisis, we will accept texts in the following languages: English, Spanish and German and we will translate them for a publication in French.

Please send your text at: contact.rfst@gmail.com 


\section{AUTHORS}

SOPHIE BAUDET-MICHEL

Maître de conférences, Université de Paris 7, UMR 8504 Géographie-Cités

EMMANUEL ELIOT

Géographe, Université de Rouen

\section{YOHAN FAYET}

Chargé de recherche CNRS, Université Claude Bernard Lyon 1, Equipe EMS - Centre Léon Bérard Lyon

\section{SÉBASTIEN FLEURET}

Directeur de recherche CNRS, Université d'Angers, UMR 6590 Espaces et Sociétés (ESO) 